\title{
THE EVALUATION OF EFFICACY OF VALBAZEN (PFLIZER) \\ IN THE TREATMENT OF GASTRO-INTESTINAL TRACT PARASITE INVASIONS IN BEEF CATTLE OF WEST POMERANIA
}

\section{OCENA SKUTECZNOŚCI PREPARATU VALBAZEN (PFLIZER) W ZWALCZANIU INWAZJI PASOŻYTÓW PRZEWODU POKARMOWEGO U BYDŁA MIĘSNEGO Z TERENU POMORZA ZACHODNIEGO}

\author{
Department of Biotechnology of Animal Reproduction and Environmental Hygiene \\ West Pomeranian University of Technology, Szczecin, Poland
}

\begin{abstract}
Streszczenie. Celem badań było ustalenie ekstensywności i intensywności zarażenia pasożytami przewodu pokarmowego bydła mięsnego rasy Limousine z terenu Pomorza Zachodniego oraz ocena skuteczności preparatem Valbazen firmy Pfizer w ich zwalczaniu. Ekstensywność zarażenia bydła pasożytami przewodu pokarmowego przed odrobaczaniem wyniosła $100 \%$. U badanych zwierząt stwierdzono obecność nicieni żołądkowo-jelitowych, pierwotniaków z rodzaju Eimeria oraz tasiemców z rodzaju Moniezia sp. Ekstensywność zarażenia bydła nicieniami żołądkowo-jelitowymi i tasiemcami z rodzaju Moniezia sp. wyniosła 97,8\%, natomiast pierwotniakami z rodzaju Eimeria - 86,7\%. Skuteczność Valbazenu ustalono w 21 dniu po podaniu preparatu. Wyniki badań wykazały wysoką skuteczność odrobaczania preparatem Valbazen firmy Pfizer. Przeprowadzone badania potwierdziły, że problem występowania pasożytów przewodu pokarmowego u bydła mięsnego w dalszym ciągu jest aktualny. Wskazuje to na potrzebę prowadzenia przesiewowych badań bydła w stadach mięsnych.
\end{abstract}

Key words: cattle, deworming, digestive tract parasites, West Pomerania.

Słowa kluczowe: bydło, odrobaczanie, pasożyty przewodu pokarmowego, Pomorze Zachodnie.

\section{INTRODUCTION}

The gastro-intestinal parasites in cattle constantly remain a severe risk for animal health and welfare (Maqbool et al. 2016). The infections mostly run in a subclinical form and usually are unnoticeable, and therefore are often underestimated by farmers. It is a reasonable problem in cattle farming, as the presence of parasites in an organism may lead to a decrease in animal welfare, health status and productivity (Chattopadhyay and Bandyopadhyay 2013; Laha et al. 2013; Geurden et al. 2015; Peña-Espinoza et al. 2016).

The most common endoparasites in cattle are the gastro-intestinal nematodes, Moniezia sp. tapeworms and Eimeria sp. protozoa. Their widespread dissemination in the environment

Corresponding author - Adres do korespondencji: Marta Juszczak, Department of Biotechnology of Animal Reproduction and Environmental Hygiene, West Pomeranian University of Technology, Szczecin, Klemensa Janickiego 29, 71-270 Szczecin, Poland, e-mail: mk.juszczak@o2.pl 
causes that these parasites are present in practically every sinle herd, regardless of climatic conditions, type of farming or age of animals (Chattopadhyay and Bandyopadhyay 2013; Geurden 2015).

Regarding the fact that farm bred animals are susceptible to many parasitic diseases which may cause severe economic losses, it is strongly justified to undertake the properly aimed prophylactic counteractions. Such activity should base on a correct identification of specific composition of gastrointestinal parasitic microflora, assessment of extensity and intensity of an infection, proper selection of a deworming agent, evaluation of deworming accuracy, and disinfection of cowsheds and pastures as well.

Not only the specific composition of parasitic microflora should be a factor that determines the choice of a deworming agent. Also the fact that the popularity of deworming agents and their common use have both caused a growth in a drug resistance of parasites ought to be taken into consideration. For this reason it is worth to develop a proper strategy of parasite counteracting, built on a constant control of animal health status, proper specimen selection and assessment of efficacy of deworming agents. Such approach will allow to minimize the productivity losses and help to keep a good health status of animals (Maqbool et al. 2016). It is also worth mentioning that prophylaxis is the most important element in parasitic infections' counteraction, and its main targets are to restrain the contact between a parasite and a host and to eliminate all the developmental stages of parasites in an environment.

The studies on parasitic microflora in beef cattle have a considerable practical application, as they allow to identify the specific composition of parasites in an organism of a host and to assess the effect of environmental factors on a parasitic invasion. All this contributes to the development of an accurate prophylactic program.

The aim of the study was to evaluate the extensity and intensity of gastro-intestinal parasitic infections in Limousine beef cattle in West Pomerania, Poland, and to assess the treatment efficacy of Valbazen (Pfizer Inc., USA) in curing of cattle parasitic infections.

\section{MATERIAL AND METHODS}

The research material included fecal samples collected from Limousine beef cattle in West Pomerania, Poland. In total, 123 fecal samples were examined (45 samples before deworming, 40 samples in the day of deworming and 38 samples on the 28 . day after deworming).

The cattle breeder was using the veterinary services occasionally, usually only after identifying any health problems in animals.

Each of the animals was dewormed individually with Valbazen by Pfizer, USA $(7.5 \mathrm{ml} / 100 \mathrm{~kg}$ b.w.) by a vet, and the active substance of Valbazen bases of the derivatives of benzimidazole. The extensity and intensity of infection with gastro-intestinal parasites was evaluated by a coproscopic examination, with the floating Willis - Schlaf's and Mc - Master's methods (Ziomko et al. 1995). There was no differentiation of larvae of invasive nematodes.

The fecal egg count reduction test may be used for the assessment of treatment efficacy in invasions caused by gastro-intestinal nematodes, and this method is recommended by the World Association for the Advancement of Veterinary Parasitology. Anthelmintic efficacy was calculated by the fecal egg count reduction (FECR) test (Coles et al. 1992), according to the following formula: 


\section{FECR $(\%)=$ Pre-treatment EPG - Post-treatment EPG $\times 100$}

\section{Pre-treatment EPG}

The efficacy of the drug was assessed on the 21. day after the specimen administration. No Eimeria sp. were considered in the evaluation of the specimen's efficacy, as this drug is not dedicated to counteract protozoal infections. The antiprotozoal agents represent a separate group of drugs and are used for counteracting the protozoal infections only.

\section{RESULTS AND DISCUSSION}

The extensity of cattle infection with gastro-intestinal parasites before the performing of deworming procedure was $100 \%$. All the examined animals were infected with gastro-intestinal nematodes, Eimeria sp. protozoa and Moniezia sp. tapeworms. The extensity of infection with gastro-intestinal nematodes and Moniezia sp. tapeworms was $97.8 \%$, and in Eimeria sp. $86.7 \%$, respectively. The results of our study indicate a common presence of digestive tract parasites in beef cattle from West Pomerania. Similar observations were made by Fudalewicz-Niemczyk and Nowosad (1981), who have noted that the extensity of cattle infections in a large-scale farming ranges from $60 \%$ to $100 \%$. The authors have indicated that the animals kept on pasture were more exposed to gastro-intestinal parasite invasions in comparison to animals maintained in cowsheds. The identical results were obtained also by Nowosad et al. (1995). The cows examined in our study were kept in free grazing pasture system which most probably could have caused the high extensity of infection of digestive tracts of animals. Similar results of the studies undertaken in kujawsko-pomorskie voivodship were obtained by Michalska and Budzińska (2004), where the mean extensity of gastro-intestinal nematode infection in three individual farms was from $25 \%$ to $100 \%$. The lower extensity was in turn indicated by Pilarczyk et al. (2011), in cows imported to Poland $50.85 \%$. Animals transported from Germany were infected with gastro-intestinal nematodes in $70 \%$, from Czech Republic in $48.36 \%$, and from France in $42.86 \%$. The problem of gastrointestinal nematode invasion does not concern Poland only, and also other countries are involved. Pavlásek (1995) has found a high extensity of infection with gastro-intestinal parasites in heifers imported to Czech Republic from France, Denmark, Netherlands and Germany (91.2-100\%). In Belgium, the extensity of gastro-intestinal parasite infection was 75\% (Agneessens et al. 2000), in Serbia 64.17\% (Kuliśić et al. 2012), and in Germany 42.2\% (Kemper and Henze 2009).

No presence of eggs of gastro-intestinal parasites was observed on the 21. day after performing the deworming procedure (gastro-intestinal nematodes, Moniezia sp. tapeworms). On the 28 . day after deworming, the presence of Moniezia sp. tapeworms was noted $(2.63 \%)-$ Table 1.

Basing on the presented analysis, we have noted the significant differences in the intensity of infection with gastro-intestinal parasites (nematodes and Moniezia sp.tapeworms) in beef cattle, after using the Valbazen specimen (Table 1). The results of the study show a high deworming efficacy of Valbazen by Pfizer. Many factors affect the effectiveness of deworming procedure, including the way of specimen administration (dosing appropriate to body weight) and time of drug administration (the animals were dewormed right after leaving the pasture). It is worth mentioning that each animal has undergone the dewormed procedure individually. 
Table 1. The infection of beef cattle with gastro-intestinal parasites before and after the deworming procedure

Tabela 1. Zarażenie bydła mięsnego pasożytami przewodu pokarmowego przed odrobaczeniem i po nim

\begin{tabular}{|c|c|c|c|c|c|c|c|c|}
\hline \multirow[b]{2}{*}{$\begin{array}{l}\text { Species } \\
\text { Gatunek }\end{array}$} & \multicolumn{3}{|c|}{$\begin{array}{c}\text { Extensity of infection } \\
\text { Ekstensywność zarażenia [\%] }\end{array}$} & \multicolumn{3}{|c|}{$\begin{array}{c}\text { EPG (number of eggs in } 1 \mathrm{~g} \text { of feces) } \\
\text { EPG (liczba jaj w } 1 \mathrm{~g} \text { kału) }\end{array}$} & \multicolumn{2}{|c|}{$\begin{array}{c}\text { Dewormin efficacy } \\
\text { Skuteczność odrobaczania [\%] }\end{array}$} \\
\hline & $\begin{array}{c}\text { before } \\
\text { deworming } \\
\text { przed } \\
\text { odrobaczaniem }\end{array}$ & $\begin{array}{c}\text { on 21. day after } \\
\text { deworming } \\
21 \text { dni po } \\
\text { odrobaczaniu }\end{array}$ & $\begin{array}{c}\text { on 28. day after } \\
\text { deworming } \\
28 \text { dni po } \\
\text { odrobaczaniu }\end{array}$ & $\begin{array}{c}\text { before } \\
\text { deworming } \\
\text { przed } \\
\text { odrobaczaniem }\end{array}$ & $\begin{array}{l}\text { on 21. day after } \\
\text { deworming } \\
21 \text { dni po } \\
\text { odrobaczaniu }\end{array}$ & $\begin{array}{c}\text { on 28. day after } \\
\text { deworming } \\
28 \text { dni po } \\
\text { odrobaczaniu }\end{array}$ & $\begin{array}{l}\text { on 21. day } \\
21 \mathrm{dni}\end{array}$ & $\begin{array}{c}\text { on 28. day } \\
28 \mathrm{dni}\end{array}$ \\
\hline Moniezia sp. & 97.8 & - & 2.63 & 972 & - & 50 & 100 & 94.86 \\
\hline $\begin{array}{l}\text { Gastro- } \\
\text {-intestinal } \\
\text { nematodes } \\
\text { Nicienie } \\
\text { żołądkowo- } \\
\text {-jelitowe }\end{array}$ & 97.8 & - & 0 & 882 & - & - & 100 & 100 \\
\hline
\end{tabular}


A common use of benzimidazoles, particularly in decreased doses, contributes to enhancing the phenomenon of drug resistance in pathogens. For this reason the doses should be applied strictly to veterinary recommendations. Valbazen is an antiparasitic agent with a wide spectrum of activity, and benzimidazole and its derivatives are characterized by a high efficacy in deworming (Salahuddin et al. 2012). As shown in some literature data, this substance is highly efficient, as its mechanism of parasite metabolism inhibition bases on blocking the microtubular interactions. This leads to a disturbance in natural functions that assure the proper shape of cytoskeleton, intracellular transport and mitotic cycle which in turn disables a process of regular cellular division in parasites (Campbell and Denham 1983; Lutz 2012). It is worth mentioning that a common use of a selected group of drugs may lead to a drug resistance in parasites (Furtado et al. 2016). This phenomenon is highly unfavorable, and is often caused by performing a ,just in case" deworming procedure in many herds.

It is also worth to point out that the drugs administered to cattle have been showing their protective activity against Moniezia sp. only for a short period of time. The World Association for the Advancement of Veterinary Parasitology (WAAVP) affirms that the drug resistance is defined when the FECRT is below $90 \%$. In our study, the efficacy of Valbazen checked on day 21 . after performing the deworming procedure has reached $100 \%$. Unfortunately, on day 28 . the efficacy has decreased to only $94.86 \%$. Thus, the implemented prophylactic approach was not fully efficient for a longer period of time.

The study has confirmed that the problem of the presence of gastro-intestinal parasites in beef cattle is still live. This indicates the need to undertake the screening studies on the presence of gastro-intestinal parasites in beef cattle with cheap but efficient diagnostic methods. Such approach can allow to limit the parasite invasions in animals and in result will help to improve the productivity in animal farms.

\section{CONCLUSION}

The study has confirmed that the problem of the presence of gastro-intestinal parasites in beef cattle is still live. This indicates the need to undertake the screening studies on the presence of gastro-intestinal parasites in beef cattle with cheap but efficient diagnostic methods. Such approach can allow to limit the parasite invasions in animals and in result will help to improve the productivity in animal farms.

\section{REFERENCES}

Agneessen S.J., Claerebout E., Dorny P., Borgsteede F.H., Vercruysse J. 2000. Nematode parasitism in adult dairy cows in Belgium. Vet. Parasitol. 90, 83-92.

Campbell W.C., Denham D.A. 1983. Chemotherapy in Trichinella and Trichinosis. New York, Plenum Press, 335-366.

Chattopadhyay A.K., Bandyopadhyay S. 2013. Seasonal variations of EPG levels in gastro-intestinal parasitic infection in a southeast Asian controlled locale: a statistical analysis. Springer Plus 2, 205.

Coles G.C., Bauer C., Borgsteede F.H., Geerts S., Klei T.R., Taylor M.A., Waller P.J. 1992. World Association for the Advancement of Veterinary Parasitology (WAAVP) methods for the detection of anthelmintic resistance. Vet. Parasitol. 44, 35-44. 
Fudalewicz-Niemczyk W., Nowosad B. 1981. Survey of helminth infection in cattle under large scale and small farm managemant systems. Proceeding of the 9-th International Conference of the Word Association, Budapest July 14th, 1981. Adv. Vet. Parasitol. 40, 35-44..

Furtado L.F.V., Paiva Bello A.C.P. de, Rabelo É.M.L. 2016. Benzimidazole resistance in helminths: From problem to diagnosis. Acta Trop. 162, 95-102.

Geurden T., Chartier Ch., Franke J., Frangipane di Regalbono A., Traversa D., Samson Himmelstjerna-Samson G., Demeler J., Bindu H. 2015. Anthelmintic resistance to ivermectin and moxidectin in gastrointestinal nematodes of cattle in Europe, Int. J. Parasitol., Drugs Drug Resist. 5, 163-171.

Kemper N., Henze C. 2009. Effects of pastures' re-wetting on endoparasites in cattle in northern Germany. Vet. Parasitol. 161, 3-4, 302-306.

Kuliśić Z., Aleksić N., Dordević N., Gajić B., Tambur Z., Stevanović J., Stanimirović Z. 2012. Prevalence of gastrointestinal helminths in calves in Western Serbia. Acta Wet. 62, 5-6, 665-673.

Laha R., Das M., Goswani A. 2013. Gastrointestinal parasitic infections in organized cattle farms of Meghalaya. Vet. World. 6, 2, 109-112.

Lutz P. 2012. Benzimidazole and it's derivatives - from fungicides to designer drugs. A new occupational and environmental hazards. Med. Pr. 63, 4, 505-513.

Maqbool I., Wani Z.A., Shahardar R.A., Allaie I.M., Shah M.M. 2016. Integrated parasite management with special reference to gastro-intestinal nematodes. J. Parasit. Dis. 41, 1, 1-8.

Michalska M., Budzińska K. 2004. Ekstensywność i intensywność inwazji pasożytniczych w wybranych stadach krów mlecznych [The extensiveness and intensiveness of parasite invasions in selected herds of cows]. Zesz. Nauk. AR Wroc., Zootechnika 3(505), 173-178. [in Polish]

Nowosad B., Fudalewicz-Niemczyk W., Skalska M. 1995. The effect of the environmental and genetical factors on the gastro-intestinal nematodes infection in cattle. Acta Agr. Silv., Zootechnica 33, 81-95.

Pavlásek I. 1995. Cryptosporidia and other endoparasites in heifers imported into the Czech Republic. Vet. Med. 40, 10, 333-336.

Peña-Espinoza M., Thamsborg S.M., Denwood M.J., Drag M., Hansen T.V., Jensen V.F, Enemark H.L. 2016. Efficacy of ivermectin against gastrointestinal nematodes of cattle in Denmark evaluated by different methods for analysis of faecal egg count reduction. Int. J. Parasitol. Drugs Drug Resist. 6 , 241-250.

Pilarczyk B., Pilarczyk R., Tomza-Marciniak A., Kavetska K., Rząd I., Binerowska B., Tylkowska A. 2011. Nachweise von gastrointestinalen Nematoden und von Paramphistomum cervi bei nach Polen importierten Kühen aus Deutschland, Frankreich und Tschechien [Detection of gastro-intestinal nematodes and Paramphistomum cervi in cows imported to Poland from Germany, France, and Czech Republic]. Tierärztl. Umschau 66, 387-390. [in German]

Renwal K.K., Gupta A., Kumar N., Pilania P.K., Manohar G.S. 2016. Prevalence and risk assessment of gastrointestinal helminthoses in dairy animals of Bikaner. Rajasthan. J. Parasit. Dis. DOI:10.1007/s12639-016-0850-x.

Salahuddin, Shaharyar M., Mazumder A. 2012. Benzimidazoles: A biologically active compounds. Arab. J. Chem. 10, 157-173.

Abstract. The aim of the study was to evaluate the extensity and intensity of gastro-intestinal parasitic infections in Limousine beef cattle in West Pomerania, Poland, and to assess the efficacy of Valbazen (Pfizer Inc., USA) in a treatment of cattle parasitic infections. The extensity of parasite infections in the examined cattle before the study was $100 \%$. The study has shown the presence of gastro-intestinal nematodes, Eimeria sp. protozoa and Moniezia sp. tapeworms. The extensity of infection of gastro-intestinal nematodes and Moniezia sp. tapeworms was $97.8 \%$, whereas in Eimeria sp. $-86.7 \%$. The efficacy of Valbazen was checked on 21. day after the specimen application. The results of our study indicate a high efficacy of deworming procedure with Valbazen by Pfizer. The study has confirmed that the problem of presence of digestive tract parasites in beef cattle is still live. This in turn indicates the need of undertaking the screening studies in beef herds. 